RESEARCH ARTICLE

(D) Suleyman Gorpelioglu ${ }^{1}$

Dümeyra Gürgen ${ }^{1}$

D Cenk Aypak ${ }^{1}$

${ }^{1}$ University of Health Sciences Ankara Diskapi Yildirim Beyazit Training and Research Hospital Department of Family Medicine, Ankara, Turkey

Corresponding Author: Suleyman Gorpelioglu

University of Health Sciences Ankara Diskapi Yildirim Beyazit Training and Research Hospital Department of Family Medicine, Ankara, Turkey E-mail: sgorpelioglu@yahoo.com Tel: +905056772230

Received: 10.04.2019

Acceptance: 07.10.2019

DOI: $10.18521 / \mathrm{ktd} .551857$
Konuralp Medical Journal e-ISSN1309-3878

konuralptipdergi@duzce.edu.tr konuralptipdergisi@gmail.com www.konuralptipdergi.duzce.edu.tr

\section{HPV Frequency and Protection Behavior of Women with HPV Screening Between 30-65 Years in a Primary Health Care Center \\ ABSTRACT}

Objective: Although cervical cancer is common, because of the presence of preinvasive lesions and due to the fact that the cervix is an easily accessible organ, it is an appropriate disease for early diagnosis, prevention, treatment and even eradication. We aimed to evaluate the results of HPV-DNA screening program in women between the ages of $30-65$ in a primary care setting and to make recommendations for preventable risk factors.

Methods: In this retrospective cross-sectional descriptive study we evaluated the records of 716 women 30-65 years old who scanned for HPV between 2014-2016 in a primary health care center. In the evaluation of data obtained, descriptive statistical methods were used.

Results: The average age of women included in the study was $44.11 \pm 9.25,97.1 \%$ were married; the age of first sexual intercourse was minimum 13 maximum 34 (mean $19.76 \pm 3.67)$. Of women $20,7 \%(n=148)$, smoked in various amounts and $26,7 \%$ of them $(n=191)$ used hormonal contraceptives for varying periods of time. HPV was found in $19(2.7 \%)$ of the women. Of these, 7 (1\%) were HPV genotype-16. In terms of protection behavior the rate of those who had at least 1 gynecological examination per year was $34.2 \%(n=252)$, the rate of condom use was $21,24 \%(n=110)$. None of the women participated in the study had HPV vaccination.

Conclusions: In our study the positive rate of HPV is lower than previous published the studies done in Turkey and abroad, the high-risk HPV genotype-16 ratio was higher. We concluded that HPV vaccination, condom use and regular gynecological examination rates are inadequate in women which we included in our study and this may be due to economic reasons as well as socio-cultural factors.

Keywords: Obesity, Qualitative Research, Weight Loss

\section{Bir Birinci Basamak Sağlık Kuruluşunda 30-65 Yaş Arası Human Papilloma Virus (HPV) Taraması Yapılan Kadınlarda HPV Sıklığı ve Korunma Davranışları ÖZET}

Amaç: Her ne kadar rahim ağzı kanseri yaygın olsa da pre-invaziv lezyonların varlığı ve rahim ağzının kolay erişilebilir bir organ olması nedeniyle erken tanı, önleme, tedavi ve hatta eradikasyon için uygun bir hastalıktır. Bu çalışmada, bir birinci basamak kuruluşunda yapılan human papilloma virus (HPV) tarama programının sonuçlarını değerlendirmeyi ve önlenebilir risk faktörleri için önerilerde bulunmayı amaçladık.

Gereç ve Yöntem: Bu retrospektif kesitsel tanımlayıcı çalışmada, bir birinci basamak sağlık merkezinde 2014-2016 yılları arasında HPV taraması yapılan 30-65 yaş arası 716 kadının kayıtlarını değerlendirdik. Elde edilen verilerin değerlendirilmesinde tanımlayıcı istatistiksel yöntemler kullanıldı.

Bulgular: Çalışmaya katılan kadınların yaş ortalaması 44,11 $\pm 9,25, \% 97,1$ 'i evli; ilk cinsel ilişki yaşı en az 13 en fazla 34 idi (ortalama 19,76 $\pm 3,67$ ). Kadınların \%20,7'si $(n=148)$ sigara içmekte ve \%26,7'si $(n=191)$ farklı sürelerle hormonal bir kontraseptif yöntem kullanmaktaydı. Kadınların 19'unda (\%2,7) HPV (+) olarak bulundu. Bunlardan 7'si (\%1) HPV genotip -16 idi. Korunma davranışı açısından yılda en az 1 jinekolojik muayene yapılanların oranı\% 34,2 ( $\mathrm{n}=252)$, kondom kullanma oranı\% 21,24 ( $\mathrm{n}=110)$ idi. Çalışmaya katılan kadınların hiçbiri HPV aşısı olmamıştı.

Sonuç: Çalışmamızda, HPV-DNA pozitiflik oranı Türkiye'de ve yurtdışında yapılan çalışmalardan daha düşük olsa da yüksek riskli HPV genotip-16 oranı yüksekti. Çalışmamıza dahil ettiğimiz kadınlarda HPV aşılaması, kondom kullanımı ve düzenli jinekolojik muayene oranlarının yetersiz olduğu ve bunun sosyo-kültürel faktörlerin yanı sıra ekonomik nedenlerden kaynaklanabileceği sonucuna vardık.

Anahtar Kelimeler: HPV, Korunma, Tarama, Birinci Basamak 


\section{INTRODUCTION}

Cancer is an increasing health problem in the world and leads to a significant socioeconomic burden in societies, as well as economic and moral losses and difficulties in individuals. According to the 2018 world cancer statistics, cancer is among the leading causes of death. In 2018, a total of 18.1 million new cancer cases will develop in the world and 9.5 million deaths have been predicted. It is expected that a significant proportion of the cancer cases that will develop in the coming years will emerge in developing countries (1). Cervical cancer is the fourth most common cancer in women and second in gynecologic cancers. According to data from the World Health Organization, around 528.000 new cases of cervical cancer are reported each year around the world, and about 266.000 of them are fatal (2). More than $70 \%$ of these deaths occur in developing countries due to the lack of adequate screening programs (3). The most common risk factors of cervical cancer include smoking, long-term use (more than 5 years) of hormonal contraceptives, multiparity (more than 2 births), multiple sexual partners, early sexual intercourse and HPV detection (4-6). Today, 99.9\% of cervical cancer is known to cause HPV (Human PapillomaVirus) infection (7).

Although cervical cancer is common, because of the presence of pre-invasive lesions and due to the fact that the cervix is an easily accessible organ, it is an appropriate disease for early diagnosis, prevention, treatment and even eradication (8). For this reason, HPV screening programs have been widely applied in developed countries and it has become one of the indispensable preventive medicine applications by decreasing the incidence of cervical cancer. A similar screening program was launched in 2014 in Turkey. Then, this program was strengthened by integrating HPV tests and family physicians.

In this study, we aimed to evaluate the results of HPV-DNA screening program in women between the ages of 30-65 in a primary are setting and to evaluate the risky behaviors and to make recommendations for preventable risk factors.

\section{MATERIAL AND METHODS}

Among the 819 women aged between 30-65 who were registered to a primary care center and HPV screening was performed between 2014-2016, 716 of them who agreed to participate were included to the study.

Ethical approval for the research was obtained from Dişkapı Yıldırım Beyazıt EAH Ethics Committee with a number of $39 / 9$ on 12.06.2017.

Demographic data questionnaire created by the researchers was applied to the women included in the study by telephone or by face to face interview method. HPV screening results of women were obtained from family medicine information system records.
Women who have first sexual intercourse age before 18 , more than 2 births, smoke regardless of amount, use hormonal contraceptives over 60 months and HPV positive ones accepted as risky group for cervical cancer (9).

The data were analyzed by SPSS (Statistical Package for Social Sciences) ver.21. Descriptive statistical methods (frequency, percentage, mean, standard deviation) were used to evaluate demographic data.

\section{RESULTS}

The mean age of women participated in the study was $44.1 \pm 9.24$ years and $97.1 \%(n=695)$ were married. In terms of protection behavior the rate of those who had at least 1 gynecological examination per year was $34.2 \%(n=252)$, the rate of condom use was $21,24 \%(n=110)$. None of the women participated in the study had HPV vaccination.

Due to the reasons such as menopause, infertility and hysterectomy $27.65 \%(n=198)$ of the women did not need any family planning (FP) method. Table 1 shows the distribution of women who are required to use FP according to the methods they are currently using.

Table 1. Distribution of women who need contraception according to the methods they are currently using *

\begin{tabular}{lll}
\hline Method & $\mathrm{n}$ & $\%$ \\
\hline External ejaculation & 148 & 28,6 \\
\hline Pill (OCS) & 19 & 3,67 \\
\hline Tube ligation & 53 & 10,23 \\
\hline Vasectomy & 2 & 0,39 \\
\hline Intrauterin device & 132 & 25,48 \\
\hline Monthly injection & 2 & 0,39 \\
\hline Condom & 110 & 21,24 \\
\hline No methods & 52 & 10,04 \\
\hline Total & 518 & 100 \\
\hline$* \mathrm{n}=518$ & &
\end{tabular}

In $70.1 \%(n=502)$ of the women included in the study, there was at least one risk of cervical cancer. Of these, $55.2 \%(\mathrm{n}=277)$ had single, $34.1 \%(\mathrm{n}=171)$ had two, $8.8 \%(\mathrm{n}=44)$ had three and $2.0 \%(\mathrm{n}=10)$ there were 4 risk factors. The distribution of risk factors determined in the women included in the study is given in Table 2 .

Table 2. Distribution of risk factors for cervical cancer among women *

\begin{tabular}{lcc}
\hline Risk Factor & $\mathrm{n}$ & $\%$ \\
\hline Smoking & 148 & 20.7 \\
\hline $\begin{array}{l}\text { Hormonal contraceptive usage over } 60 \\
\text { months }\end{array}$ & 40 & 8.0 \\
\hline Births more than 2 & 371 & 73.9 \\
\hline First sexual intercourse before 18 of age & 211 & 42.0 \\
\hline HPV (+) & 19 & 3.7 \\
\hline$*$ Only who have at least one risk factor were included $(\mathrm{n}=502)$
\end{tabular}


HPVwas found in $2.7 \% \quad(n=19)$ of the women included in the study. Of these, $1 \%(n=7)$ were HPVgenotype- 16.

\section{DISCUSSION}

In our study although HPV positivity rates are lower than the rates in Turkey and abroad, we have a higher rate of high-risk HPV genotype -16 $(10,11)$. The reason for this finding can be the socioeconomic constraints in the region where we did our research or the changes in the epidemiology of the virus. It is an issue that needs to be put forward by further research.

In our study, we examined the prevention behaviors of women in cervical cancer in 2 stages. In primary protection HPV vaccination and condom use which are the most important measures against HPV transmission.

None of the women included in our study had the HPV vaccine, the most important step in the prevention of cervical cancer. This situation, may be due to concerns about vaccination among the people, such as side effects and reliability, efficacy, cost, and the false sense of security leading to "increased sexual activity with many partners" (12) - As a limitation of our study, we did not record why they are not vaccinated, but we observed that women were not vaccinated mostly for economic reasons.

The majority of women in our study $(78.6 \%)$ used scientific and traditional family planning methods which were not effective in HPV protection. Those using condoms were a group of $21.24 \%$. This rate was $19.2 \%$ in another study conducted in different regions of the same city (13).
These rates suggest that the primary purpose of condom use is to provide contraception rather than protection from infection. However, more detailed research is required to clarify this issue.

Gynecological examination is the most cost effective way of finding a condition like cervical cancer in the early stages and improving the quality of life of the patient. However, only $35.2 \%$ of the women in our study had a gynecological examination on a regular basis. In a study conducted in our country, it was determined that $18.3 \%$ of women had never been examined before and $66.3 \%$ of them had been examined 1 to 5 times throughout their lifetime (14). In another study, the rate of routine gynecological examination without any complaints was $15 \%(15)$. We thought that the high rates in our study was due to the fact that the women included in the study considered the examinations performed during pregnancy and delivery as a gynecological control examination.

As a conclusion, it was shown that HPV vaccination, condom use which are the primary prevention of cervical cancer, as well as regular gynecological examination, which is secondary protection, are insufficient in our study group. We conclude that the this shortage may be influenced by economic reasons as well as sociocultural factors. This deduction once again revealed the importance of state-supported programs in order to increase personal protective behaviors.

We thought that performing of HPV screening programs would be more appropriate for primary care physicians because the women would feel less anxious when they were examined by them as they were familiar and easily accessible.

\section{REFERENCES}

1. Bray F, Ferlay J, Soerjomataram I, et al. Global cancer statistics 2018: GLOBOCAN estimates of incidence and mortality worldwide for 36 cancers in 185 countries. CA Cancer J Clin 2018 Nov;68(6):394-424.

2. Jaime Prat, Silvia Franceschi. Cancers of the female reproductive organs. In: World cancer report 2014 (ed) Bernard W. Stewart and Christopher P. Wild. International Agency for Research on Cancer 2014; Lyon pp: 465-81

3. Turgay AS, Khorshid L, Eser I. Effect of the first chemotherapy course on the quality of life cancer patients in Turkey. Cancer Nursing 2008;31:1-5.

4. Xavier Castellsague', Nubia Munoz. Cofactors in Human Papilloma virus Carcinogenesis Role of Parity, Oral Contraceptives, and Tobacco Smoking. J. Natl. Cancer Inst. Monogr. 2003; 31:20-8

5. Gierisch JM, Coeytaux RR, Urrutia RP, et al. Oral contraceptive use and risk of breast, cervical, colorectal, and endometrial cancers: a systematic review. Cancer Epidemiol Biomarkers Prev 2013; 22(11):1931-43.

6. Muñoz N, Franceschi S, Bosetti C, et al. Role of parity and human papilloma virus in cervical cancer: the IARC multicentric case-control study. Lancet 2002; 359(9312)1093-101.

7. Andrae, B, Kemetli L, Sparén P, et al. Screening-preventable cervical cancer risks: evidence from a nation wide audit in Sweden. J Natl Cancer Inst 2008; 100(9): p. 622-9.

8. Muñoz N1, Bosch FX, de Sanjosé S, et al. Epidemiologic classification of human papilloma virus types associated with cervical cancer. N Engl J Med 2003; 348(6): 518-27

9. Tasalı N, Çubuk R, Midi A, et al. Serviks Kanserinde Radyolojik Görüntüleme. Konuralp Tıp Dergisi 2010;2(2):33-38.

10. Karaca ZM. Kanser haftası 2018 taramalarda güncel durum. https://hsgm.saglik.gov.tr/depo/birimler/kanserdb/yayinlar/sunular/ulusal_kanser_haftasi_2018/Mujdegul_Karaca-2018.pdf (Erişim: 06.02.2019)

11. Martel C, Plummer M, Vignat J, et al .Worldwide burden of cancer attributable to HPV by site, country and HPV type. Int J Cancer. 2017; 141: 664-670

12. Şahbaz A, Erol O. HPV aşı uygulamaları. J Turk Soc Obstet Gynecol. 2014; 2:126-30. 
13. Kahraman K, Göç G, Taşkın S, et.al. Kontraseptif yöntem seçimini etkileyen faktörler: Bir üniversite hastanesi deneyimi. J Turkish-German Gynecol Assoc. 2012; 13: 102-5.

14. Erbil, N., Şenkul, A., Sağlam, Y., et al. Jinekolojik muayene öncesinde Türk kadınların anksiyete seviyeleri ve muayeneye ilişkin tutumlarının belirlenmesi. Uluslararası İnsan Bilimleri Dergisi 2008; 5(1): 1-13.

15. Esencan TY. Jinekolojik erken tanı yöntemlerinin kullanımında kadınların tutum ve davranışlarının değerlendirilmesi. Zeynep Kamil Tip Bülteni 2009; 40 (2): 63-6. 